\title{
REGULATION OF ENGAGEMENT IN THE NEW ROMANIAN CIVIL CODE $^{1}$ AND OTHER INTERNATIONAL LEGISLATIONS
}

\author{
M. C. Ghilea
}

\section{Marta Cornelia Ghilea}

Faculty of Law, Private Law

"Vasile Goldiş" Western University of Arad, Romania

*Correspondence: Marta Cornelia Ghilea, "Vasile Goldiş" Western University, 94 Revoluției Blvd, Arad, Romania

E-mail: marta_ghilea@yahoo.com

\begin{abstract}
Engagement is making a comeback to the landscape of the new Romanian civil legislation, being known that it has deep roots in the history of Romanian law. The institutionalization of engagement was justified by experts as a traditional reality in Romania. This article investigates aspects concerning the evolution of engagement, the content of this sui generis legal act, its legal nature, the substantive and procedural conditions, as well as considerable issues relating to the legal effects of engagement, particularly its rupture.
\end{abstract}

Keywords: new Civil Code, engagement, liability.

\section{Introduction}

Our old legislations, namely the Calimach, Caragea and Donici Codes, have regulated engagement as a pre-contract binding the parties to marriage. Subsequently, the Romanian Civil Code, following the model of the French Civil Code, and then the Family Code, did not regulate engagement, in order to give absolute consistency to matrimonial freedom. The institution of engagement is considerably old, being even mentioned in the Old Testament, where it was represented by the Hebrew word "aras", meaning marriage commitment or marriage covenant. Engagement, a symbol of the union between a man and a woman, after their solemn covenant to marry, was also present in Roman law ${ }^{2}$, as designated by the term "sponsalia". From a spiritual standpoint, engagement is almost as important as marriage, as it signifies a confession of mutual feelings and a vow to enter into marriage, while it may also imply the blessing of the relationship by the parents and by the Church. But engagement is legally important only to the extent as the law recognizes it as such.

\section{A. The place of engagement}

Currently, "engagement" as a civil law institution is inseparably linked to marriage and is governed by the provisions of Art. 266-270 contained in Book II - On Family, Title IIMarriage, Chapter I - Engagement, of Law no. 287 of 17 July 2009 on the Civil Code, as republished.

\footnotetext{
${ }^{1}$ New civil Romanian Code, Law no. 287/2009, published in the Official Gazette of Romania, Part I, no. 511 of 24 July 2009.

${ }^{2}$ I. Chelaru, Marriage and divorce. Judicial issues on civil, religious and comparative law matters, A92 Acteon Publishing House, p. 27.
} 
We emphasize that engagement is specifically regulated in international legislations, such as the German Civil Code ${ }^{3}$, the Swiss Civil Code ${ }^{4}$, the Italian Civil Code and the AngloSaxon system, etc.

\section{$B$. The definition and legal nature of engagement}

According to the New Civil Code, engagement is defined as "mutual promise to enter into marriage."

Engagement is nothing but a mutual promise of marriage, a solemn covenant of two persons of opposite sexes to marry, which is usually done in a festive setting. Engagement, in the view of the New Civil Code, is a social, moral and cultural relationship, with possible legal consequences for unilateral and abusive rupture.

Engagement is a civil law institution, included and addressed in the new legal structure of regulations on family life. The new Civil Code also defines marriage as "(...) freely consented union between a man and a woman, entered into under the law".

In the academic literature, engagement is not considered to be a contract, but a simple legal fact which can produce, at the most, extrinsic effects to marriage, especially in the case of unilateral and abusive rupture.

However, there are also views that share the contractual hypothesis of engagement, considering that denying the contractual aspect of engagement would be divergent to psychological and social reality. The argument of these views lies in the fact that the contract does not have the contents of a pre-contract of marriage, so that the parties would not commit to enter into marriage, but only pledge to loyally try to establish such relationship as to be likely to lead to marriage.

Thus, matrimonial freedom would not be reached because either party may unilaterally terminate the contract at any time, and, as such, they cannot be held responsible unless the termination was abusive. Therefore, the engagement contract leads to the same practical consequences as the classification of engagement as a simple legal fact.

Recently, according to an emerging view in the academic literature, based on the confrontation of the two pieces of legislation, it can be seen that, while for engagement the agreement of will is highlighted exclusively, emphasis in marriage is placed on the legal status subsequent to the expression of consent ${ }^{5}$.

According to this view, differentiation is not justified, since both institutions stem from a legal act and generate a legal provision, a statute governed by law and which cannot be neglected.

For these reasons, the term of "engagement" may be given two meanings:

a. that of a legal act;

b. that of a legal status.

Thus, engagement is defined as a legal act in which the future betrothed mutually promise, by prior agreement, to meet a common goal, namely "entering into marriage", which can lead us to the idea of convention, following the synallagmatic promise to enter into marriage ${ }^{6}$.

Therefore, we acquiesce in the view that engagement is a sui generis legal act, which entails a certain legal status for the betrothed, thus agreeing with the definition given to engagement, according to which it is a facultative legal status, prior to marriage, stemming from the mutual promise made, under the law, between a man and a woman, to enter marriage ${ }^{7}$.

\section{The legal characters of engagement}

\footnotetext{
${ }^{3} 1900$ German Civil Code, art. 1297-1302.

${ }^{4}$ Swiss Civil Code, art. 90-93.

${ }^{5}$ Lupaşcu, D., Crăciunescu, C.M., op. cit., 2011, p. 38

${ }^{6}$ E. Florian, op. cit. 2009, p. 632-633.

${ }^{7}$ Ibidem, p. 39
} 
The institution of engagement, according to the regulations of the New Civil Code, has the following legal characters:

1. Engagement is a union between two people

The act of engagement admits an association between two individuals for the achievement of a common goal, namely entering into marriage.

2. Engagement is concluded between a man and a woman - engagement is monogamous

As a legal provision prior to marriage, engagement assumes this essential character of marriage, being forbidden to people of the same sex.

On the other hand, as marriage is controlled by the principle of monogamy, as a result of the exclusive nature of the feeling of love, those engaged cannot enter into another engagement, as long as the previous one has not ended (lato sensu).

3. Engagement is freely consented marriage.

No circumstances can prevent such persons from promising each other to enter into

4. Engagement is consensual

In accordance with Art. 266 para. (3) thesis I of the new Civil Code: "Entering into an engagement is not subject to any formality..."

Consequently, no action is required from any authority to ascertain engagement, the parties having full autonomy to decide on how to tangibly express their consent.

Unlike marriage, where the Constitution itself provides for the possibility of religious celebration, occurring necessarily after the civil marriage ${ }^{8}$, engagement has no such regulations, but it can be traditionally celebrated religiously.

5. The engagement is entered into until marriage

According to our ancient statutes, engagement had to be followed, within two to four years, by marriage, but the new Civil Code does not establish any such term for engagement.

For this reason, the parties may agree, during the engagement, on the date of marriage, just as they are free to not settle anything in this regard. Whichever variant is chosen, the legal status of engagement cannot exceed the time of marriage.

6. Engagement is based on equal rights and obligations of the engaged persons

Equality between men and women exists in all areas of social life ${ }^{9}$. In terms of engagement, this equality refers to both the conditions and the relationship between those engaged.

7. Engagement is entered into only for the purpose of marriage

The mutual promise of the parties concerns entering into marriage, the aim of which is to start a family.

\section{Substantive conditions}

According to art. 266 para. (2) of the new Civil Code, "Provisions relating to the substantive conditions for entering into marriage shall apply accordingly, except for medical certification and the approval of the guardianship court."

Therefore, the substantive conditions for an engagement take two forms ${ }^{10}$ : an engagement;

- positive conditions - substantive requirements that must exist in order to enter into

- negative conditions - impediments (impediments to engagement), de facto or de jure states that must not exist in order to enter into an engagement.

From the above we conclude that only those who fulfill the necessary conditions for marriage may become engaged.

\footnotetext{
${ }^{8}$ Art. 48 para. (2) thesis II of the Romanian Constitution, as republished.

${ }^{9}$ Law no. 202/2002 on equal opportunities and treatment between men and women, republished in the Official Gazette, Part I, no. 150 of 1 March 2007.

${ }^{10}$ E. Florian, op. cit. 2011, p. 14.
} 


\section{Positive substantive conditions for engagement}

Analyzing the provisions of art. 271-277 of the new Civil Code, on the substantive conditions for marriage, we note that engagement requires meeting three cumulative substantive requirements: age required for engagement, consent to engagement, and difference of sex.

\section{Age required for engagement}

By custom, engagement can be entered into only if both parties are aged over 18 . Therefore, it is civil adulthood that is relevant here, and not the acquisition of full capacity of exercise $^{11}$.

According to art. 272 para. (2), as an exception, the minor who has reached the age of 16 can be engaged with the consent of their parents or, where applicable, guardian, only if there are "reasonable grounds" that the law does not define ${ }^{12}$.

However, in case of disagreement between the parents on consenting to the engagement, it is the guardianship court ${ }^{13}$ that decides, in the best interest of the child.

If one parent is deceased or is unable to manifest their will, the consent of the other parent will suffice. Also, in the case of shared custody, the consent of the parent exercising parental authority is sufficient.

If there are no parents or guardian, it is indispensable to obtain the consent of the person or, where appropriate, the authority entitled to exercise parental rights.

The approval of engagement is an element of parental care, being essentially a unilateral legal act, revocable until entering the engagement ${ }^{14}$.

As in the case of child marriage ${ }^{15}$, both the abusive refusal to consent to the engagement and the abusive revocation of consent can be appealed to in court, following the path of non-contentious procedure.

Legal norms do not impose any formal requirements for consent, in which case we believe that it can be given either verbally or in writing.

\section{Consent to engagement}

The consent to engagement is the manifestation of the will of the two people who wish to become engaged, being subject to the following conditions:

a. it must come from a discerning person, i.e. a person who has both intellectual and volitional capacity. Lack of judgment entails lack of consent;

b.it must be personally expressed by those who wish to become engaged; engagement by representation is not allowed ${ }^{16}$;

\footnotetext{
${ }^{11}$ For the capacity to enter into an engagement, see also art. 90 parag. (2) of the Swiss Civil Code.

${ }^{12}$ The same situation occurs in the case of child marriage. De lege lata, regarding the content of "reasonable grounds", the doctrine held such grounds to be: pregnancy, childbirth, serious illness, concubinage, etc. (See, e.g. I.P. Filipescu. A.I. Filipescu - Treatise of Family Law, Eighth edition, as revised and supplemented, "Universul Juridic" Publishing House, Bucharest, 2006, p. 12; A. Bacaci, V. Dumitrache, C. Hageanu - Family Law, "All Beck" Publishing House, Bucharest, 1999, pp. 18-19; E. Florian - Family Law, "Limes" Publishing House, Cluj Napoca, 2003, p. 26-27.

13 According to the 1864 Civil Code, as amended in 1906, for the boy and girl under 21 who wanted to marry, parental consent was necessary, and in case of disagreement between the parents, the father's consent was sufficient (art. 131). If both parents were dead or unable to manifest their will "then the grandfather and the grandmother from the father's side and, in their absence, the grandfather and the grandmother from the mother's side, shall replace them", and in the absence of grandparents, the guardian's consent was required (art. 133). With reference to: C. Hamangiu, N. Georgean - Annotated Civil Code, Vol. I (republished), All Beck Publishing House, Bucharest, 1999, pp. 175 - 176.

${ }^{14}$ Similarly, on the analysis of the requirements for age exemption for child marriage, with reference to: F.A. Baias, M. Avram, C. Nicolescu - Amendments to Family Code brought by Law no. 288/2007, in „Law” Review no.3/2008.no.3/2008, pp. 9-41.

${ }^{15}$ F.A. Baias, M. Avram, C. Nicolescu - op. cit., p. 18.

${ }^{16}$ In Roman law, the matchmaker or marriage mediator (proxeneta or conciliator nuptiarum) was entitled to payment (Proxenetica jure licito petuntur). Here this convention was regarded as contrary to morality, being invalid, so that the matchmaker did not receive any payment. (See: D. Alexandresco - op. cit., p. 142).
} 
c. it must be free, in the sense that there is no obstacle in choosing the future betrothed.

In the legal sense, consent is free if there are no vices of consent;

a. it must be full, i.e. unaffected by modalities (term, condition, load);

b. it must be expressed without doubts.

As in the case of marriage, consent may be vitiated by error, fraud or violence.

Difference of sex

Engagement can only occur between a man and a woman. Although an express provision to this effect was not required - given the general reference made by art. 266 para. (2) to the substantive conditions of marriage - however, the legislator sought to remove any doubt ${ }^{17}$.

Unlike the other rights and freedoms guaranteed by the European Convention on Human Rights as belonging to any person, that no one shall be subjected to torture or degrading treatment, forced labor or being convicted twice for the same offense, the wording of art. 12 states that, as soon as they have reached the legal age for marriage, a man and a woman have the right to marry. The text does not state that any person has the right to enter into marriage. The difference is fundamental, as it reflects the idea that the right to marry is only recognized to people who have a different biological sex ${ }^{18}$.

2. Negative substantive conditions for engagement. Impediments to engagement

There are de facto or de jure states that must not exist in order to enter into an engagement:

Civil status as married person or an engaged person

According to the new Civil Code art. 273 Bigamy "It is forbidden for a person who is already married to enter into a new marriage. The provision is also applicable to engagement. Therefore, a married person cannot be engaged to another person."

Likewise, given the specificity of marriage and its basis, we believe that people who are already engaged may not enter into another engagement.

\section{Kinship}

It is necessary to distinguish between direct relatives, for whom engagement is prohibited regardless of degree, and collateral relatives, for whom engagement is forbidden only up to the fourth degree. For reasonable grounds, as in the case of engagement between minors, collateral relatives of the fourth degree (i.e. cousins) may be engaged.

Adoption

According to art. 451 of the new Civil Code: "Adoption is the legal operation which creates a parental relationship between the adopter and the adoptee, as well as kinship between the adoptee and their adoptive relatives."

As a result, engagement is prohibited between the adoptee and their adoptive relatives, in the same situations as between natural relatives, as provided in para. (3) art. 274 of the new Civil Code regarding marriage.

Guardianship

A guardian, for moral reasons, cannot be engaged to the minor person under guardianship, as between these two people there is a prohibition to marry. During guardianship, marriage, as well as engagement, is forbidden between the guardian and the minor person under guardianship (art. 275 Civil Code).

Mental alienation, mental deficiency or temporary lack of mental faculties

According to art.276 of the new Civil Code, "it is forbidden to marry a mentally alienated or mentally deficient person."

Consequently, the mentally alienated or mentally deficient person cannot be engaged, regardless of whether or not they are subject to a prohibition order.

\footnotetext{
${ }^{17}$ Art. 266 para. (5) of the new Civil Code.

${ }^{18}$ C. Bîrsan, The European Convention of Human Rights, vol. I, p. 850.
} 
In the case of temporary lack of mental faculties (intoxication, hypnosis, delirium, etc.), engagement is prohibited just as long as they are devoid of judgment.

\section{E. Formal requirements for engagement}

Dominated by the principle of mutual consent, engagement is not subject to any formality and may be proved by any available means according to art. 266 para. (3) of the new Civil Code. However, it is considered that nothing prevents the parties from concluding an official engagement (e.g. before a notary public, priest, etc.) by recording the mutual promise to marry in writing.

Legal regulations do not impose any requirement relating to the bestowing of goods (engagement ring, any other gifts), so that their absence does not affect the validity of the engagement. either.

Engagement does not necessarily imply factual cohabitation, but does it not exclude it,

Consensual union (concubinage), as a tolerated matter of fact, but not regulated by law, is characterized by stable and continuous cohabitation, without interfering necessarily with any commitment to marriage; on the contrary, engagement is a mutual marital promise that does not inevitably entail the cohabitation of the betrothed. Obviously, concubinage and engagement are not incompatible; they are not mutually exclusive. We believe, however, that consensual union can bear the meaning of a tacit mutual promise of marriage; since engagement is confirmed by any available means, including presumption; it can be supposed that cohabitation organized like a marriage is, according to the will of the parties, a premarital stage $^{19}$. Likewise, it is not required for an engagement to be recorded in the registries of any institution.

\section{F. Proof of engagement}

Under the provisions of art. 266 para. (3) of the new Civil Code, proof of engagement can be made by any available means (questioning, witnesses, presumptions, documents, etc.) permitted by law, or as a contract (when applying the rule of moral impossibility to reconstruct a document $)^{20}$.

Engagement can be confirmed by any available means; although the administration of evidence may seem very easy, in practice there may be difficulties in establishing the facts, as the actual relationship between the betrothed is difficult for others to assess objectively.

$G$. The effects of engagement

From the perspective of promised marriage, engagement is neither a necessary "preamble" to marriage, nor a guarantee of its materialization, as it is not binding.

The appropriation of the matrimonial engagement convention is made if both the engagement and the matrimonial convention precede marriage. Engagement consists of mutual promises of marriage. Matrimonial convention is concluded as custom before marriage, to enter into marriage.

The new Civil Code does not show the effects of engagement, but merely regulates the predominantly economic consequences of breaking the engagement.

The legal act of engagement generates the legal status of engaged persons. Hence, there are a number of moral, as well as legal consequences.

Engagement brings no rights and duties of a personal or economic nature binding the betrothed, regardless of how much the marital promise would be delayed.

The analogy with marriage provisions relating to the rights and duties of spouses is out of the question. It is only the substantive conditions of marriage that apply to engagement, excepting medical certification and the approval of the guardianship court.

\footnotetext{
${ }^{19}$ E. Florian, op. cit., 2011, p. 15.

${ }^{20}$ M. Avram, C. Nicolescu, op.cit., 2010, p. 71.
} 
A special relationship is created between the two (man and woman), which must dominate their behavior in achieving the mutual promise to marry. In terms of religious doctrine, engagement is a form of "moral and spiritual kinship."

From the perspective of punishing the person who breaks the engagement abusively or who, by fault, causes the other to break the engagement, we may state that there are a number of personal rights and obligations between the betrothed, similar in principle to those of marriage.

Thus, as an expression of full equality of rights and obligations, the betrothed mutually agree on everything that concerns marriage.

However, without indicating equality between the two legal institutions, given that both are based on friendship and affection between a man and a woman, we believe that it is not exaggerated to support the existence of mutual obligations (respect, fidelity and moral support).

Apart from the rights and obligations arising from the nature of engagement, we believe there may be other reciprocal rights and obligations in relation to the actual content of the agreement between the parties.

While in the past engagement necessarily required adherence to a vow of chastity until the religious ceremony and, especially, the spiritual purification of the intending spouses, today they can agree to live and to manage a household together, in which case the engagement can be superimposed on the state of concubinage.

If children were born out of the relation between those engaged, they are born out of wedlock, according to the relevant legal regime.

The betrothed can choose the matrimonial regime, agreement which will take effect from the time of marriage. From this point of view, they have the following options: legal community; separation of goods; conventional community. If they choose a different matrimonial regime than that of legal community, this must be submitted to the notary public to conclude a matrimonial convention, which takes the form of an authentic document.

Since the betrothed are not subject to the matrimonial regime, property that had been acquired jointly during the engagement period is subject to the rules of co-ownership (shared ownership by quotas). Note that there is even a presumption of co-ownership, in the case of jointly owned property ${ }^{21}$.

In considering engagement or throughout its duration, with a view to marriage, the betrothed can make gifts to one another (donations, by the rules of common law) or receive gifts from third parties. This latter option can take the form of legacy or donation, and the nature of ownership on that property will be set according to the will of the original owner.

The betrothed may agree to give each other material support (the obligation to jointly bear household costs and the obligation to provide support).

The rights and obligations of the parties are assessed in relation to the determined content of the agreement between them, as are, ultimately, the potential abusive attitude of disengagement or the wrongful determination to break the engagement ${ }^{22}$.

$H$. The nullity of engagement

Given that legal norms provide that, with the exceptions mentioned above, the basic conditions for marriage are applicable to engagement, we believe that the consequence of non-compliance therewith, namely nullity, must also be accepted.

The penalty that may be applied for failure to comply with the requirements of legal norms for engagement is the nullity thereof.

Depending on the character of nullity, it is divided into absolute nullity and relative nullity.

The absolute nullity of engagement occurs in the following situations:

\footnotetext{
${ }^{21}$ Art. 633 of the new Civil Code.

${ }^{22}$ Florian, E., op., cit., 2009, p. 630.
} 
a. those people had not reached the age required for engagement;

b. the engagement occurred between two persons of the same sex;

c. the consent does not meet the conditions analyzed above;

d. the engaged person was married;

e. the people who entered into the engagement are direct relatives (regardless of degree) or collateral relatives (up to the fourth degree) For collateral relatives up to the fourth degree, if there are reasonable grounds, the engagement is valid. The case presented takes into account both natural and civil kinship;

f. the engaged person is mentally alienated or mentally deficient.

According to art. 2502 para. (2) Section 3 of the new Civil Code, the action in ascertaining absolute nullity of engagement is imprescriptible and may be brought by any interested person, including the prosecutor.

Exceptionally, in the case of non-compliance with the age required for engagement, nullity is covered if, until the final judgment, such persons have come of age.

The relative nullity of engagement occurs in the following cases:

a. the minor who has reached the age of 16 became engaged without having the consent required by law;

b. the consent of one or both of the betrothed was vitiated by error, fraud or violence;

c. on the date of the engagement, the person was temporarily devoid of judgment;

d. the guardian became engaged to a minor under their guardianship.

The action for annulment of engagement is prescribed within 6 months, running from different dates, such as:

a. in the case of lack of consent for the minor's engagement, the period runs from the date on which those called to approve the engagement have become aware of this;

b. in the case of vitiation of consent or temporal lack of judgment, the term runs from the date of termination of violence or, if applicable, the date on which the person concerned has become aware of the error, fraud or temporary lack of judgment;

c. in the case of a guardian engaged to the minor under guardianship, the period runs from the date of the engagement.

The action for annulment has a personal character and can only be initiated by one whose interest was damaged, namely: 16 ;

a. the person(s) or authority called to consent to the engagement of the minor under

b. the engaged person whose consent was vitiated;

c. the person temporarily devoid of judgment;

d. the minor under guardianship.

The right of action is not transmitted to heirs. However, if the action was initiated by its holder, it can be continued by the heirs.

In the case of engagement entered into by a minor who has reached 16 years of age, the relative nullity is covered if consent is obtained until the date of the final judgment.

The final judgment of admission for the action in ascertaining nullity or in annulling the engagement takes effect retroactively, since the date of the engagement. As a result of admission of the action, it is deemed that there was no engagement, so that it did not produce any legal consequences.

\section{Breaking the engagement and its effects}

The new Romanian Civil Code does not provide for cases where the engagement can be broken off, but only regulates the legal consequences of breaking the engagement.

Mutual commitment to enter into marriage does not endow one with the power of a legal obligation of result, each of the betrothed or both jointly are free to abandon the project 
of marriage until the marriage ceremony, being bound by the possible economic consequences incurred by them ${ }^{23}$.

Thus, as engagement is based on agreement of the parties, nothing prevents them from agreeing to break off the engagement ${ }^{24}$.

Likewise, we believe that the parties may decide to break off the engagement even in cases where the engagement would be null and void ${ }^{25}$, as long as legal inefficiency was not ascertained judicially.

As regards the formal conditions of breaking the engagement, the new civil code reprises the idea based on the principle of symmetry of form, stating that: "Breaking the engagement is not subject to any formality and can be proven by any available means."26

The main consequence of breaking the engagement is the termination of the rights and obligations arising from the act of engagement.

According to the law, the person who breaks the engagement cannot be forced to enter into marriage ${ }^{27}$. The solution is natural, since engagement is not a contract, and the consent to marry must be given voluntarily ${ }^{28}$.

The new Civil Code regulates two categories of economic effects of breaking the engagement, namely:

1. the obligation to return the gifts;

2. the responsibility for abusive breaking or, where appropriate, guiltily causing the breaking of the engagement.

Note that the economic consequences of breaking the engagement can be cumulated and that the right of action, based on art. 269 and 270 of the new Civil Code, is prescribed within a year of the date when the engagement was broken.

The obligation to return gifts

According to art. 268 para. (1) of the new Civil Code, this obligation applies to "gifts made by or received by the betrothed in consideration of the engagement or during it, with a view to entering marriage."

Although it may be presumed that the regulation is aimed mainly at gifts made between the betrothed, the correct interpretation of the text is that all gifts must be returned, including those received by one or both of the betrothed from third parties (ubi lex non distinguit, nec nos distinguere debemus). condition.

We believe that these gifts are "conditional gifts", i.e. donations subject to a resolutory

The above provision should be linked to art. 1030 para. (1) of the new Civil Code, according to which: "Donations made to intending spouses or to one of them, under the condition of entering into marriage, do not take effect if the marriage does not occur."

Although the marginal regulation of this Article refers to obsolescence, we believe that, in reality, it is the failure to fulfill a condition, because obsolescence involves the

\footnotetext{
${ }^{23}$ E. Florian, op., cit., 2011, p. 16.

${ }^{24}$ The Romans applied, here too, the principle: "Quae consensu contrahuntur, contrario consensu dissolvuntur" (contracts that are formed by consent are dissolved by contrary consent). Also, our old legislations stipulated that "the engagement is broken when, without cause, the betrothed would repent." (See: Andronachi Donici Code 'Chapter 30, § 7, and Caragea Code- Part III, Chapter 15, art. 3 letter h) - quoted by D. Alexandresco - op. cit., p. 462).

${ }^{25}$ Our old legislations mentioned that "the engagement is broken" in situations pertaining to its invalidity, such as: the engagement was not been entered into "by the will and knowledge of parents and guardians", "when there is a cause of relation" etc. [See: Code of Andronachi Donici (Chapter 30, § 7) - quoted by D. Alexandresco - op. cit., p. 461)].

${ }^{26}$ Art. 267 parag. (3) of the new Civil Code.

${ }^{27}$ Art. 267 parag. (1) of the new Civil Code.

${ }^{28}$ In the sense that "the consent of the intending spouses must be given freely and not forced, as it may not be subject to prior agreement.” (See: C. Hamangiu, I. Rosetti - Bălănescu, Al. Băicoianu - op. cit., p.188)
} 
intervention of circumstances beyond the will of the parties to the legal act ${ }^{29}$. In addition, the obligation to return these gifts is independent of the idea of guilt of one of the betrothed for breaking the engagement.

Note that, in accordance with art. 268 para. (1) of the new Civil Code, the obligation of returning gifts does not include "ordinary gifts".

a. the concept of ordinary gifts can be found in the new Civil Code in several fields such as: art. 144 para. (1) provides that a guardian cannot make donations on behalf of the minor, except for ordinary gifts, according to the financial situation of the child;

b.art. 146 para. (3) provides that the child cannot make donations, except for ordinary gifts, according to their financial situation;

c. art. 346 para. (3) provides that ordinary gifts are exempt from the rule according to which common property of spouses may be transferred only with the consent of both spouses;

d.according to art. 1091 para. (3), the line of succession is determined without regard to ordinary gifts;

e. art. 1150 par. (1) let. c) provides that ordinary gifts are not subject to the obligation of a donation report.

We believe that ordinary gifts should be assessed in relation to context or the situation of offering them (e.g. birthday), as provided by art. 144 and 146 of the new Civil Code, as well as in relation to the financial situation of the persons concerned.

However, we believe that ordinary gifts should not be confused with handmade gifts, covered in art. 1011 para. (4) of the new Civil Code, the scope of which is wider.

In the case of donated amounts of money, returning them will take into account their current value, without interest (civil fruits), as restitution is independent of the good or bad faith of the betrothed. Interest would be payable only from the date on which the return of that amount is claimed.

If restitution in kind is not possible, this is done "to the extent of wealth" 30 .

In case restitution in kind is no longer possible, the gifts or cash equivalent can be returned either voluntarily or through a court action.

In the latter case, the right of action is prescribed within one year, which commences after the date when the engagement was broken ${ }^{31}$.

French courts tend to favor the category of ordinary gifts, refusing restitution claims unless the disputed property has an evidently important value relative to the donor's material possibilities - for example, it is 6 times their monthly salary or consists of family jewels. As regards family jewels, they were deemed to have a special regime: they were given as a donation (handmade gifts) but on loan of use and they had to be returned to be kept in the family.

In French doctrine, the solution is based on art. 1088 of the French Civil Code, which states that any donation made for the purpose of marriage becomes obsolete if the marriage ends. Such regulations can also be found in other legislations such as those of Germany and Switzerland. Engagement is expressly provided for with the effects discussed above in European legislations, such as the German Civil Code, the Swiss Civil Code, etc.

Responsibility for abusive termination of the engagement

According to art. 269 of the Civil Code "The party who breaks the engagement abusively can be obliged to pay compensation for expenses incurred or contracted for the purpose of marriage, to the extent that the circumstances were appropriate, as well as for any

\footnotetext{
${ }^{29}$ Obsolescence is the cause of inefficiency that consists of depriving the civil legal act validly concluded of any effects due to the occurrence of circumstances subsequent to its conclusion and which is independent of the will of the author(s) of the legal act - See: G. Boroi - Civil Law. General Part. Persons, All Beck Publishing House, 2002, p. 225.

${ }^{30}$ Art. 268 parag. (2) thesis II of the new Civil Code.

${ }^{31}$ Art. 270 of the new Civil Code.
} 
other damages caused. The party that guiltily led the other to break the engagement may be forced to pay compensation under paragraph (1)."

Therefore, liability occurs in the following cases:

- for abusive termination of engagement;

- for guiltily causing the other party to break the engagement.

In terms of liability, it is the circumstances in which the rupture occurred that matter, and not the rupture itself - this provides the context of liability - from this point of view it does not matter which of the two broke the engagement, but which one is at fault.

The key element is the existence of facts or a sequence of actions due to which the continued promise of marriage became undesirable.

As an example, inspired by the solutions given by the French courts, the fiancé's marriage to another person after the promise made to the fiancée was reaffirmed repeatedly and publicly, or the brutal manner in which the rupture occurred, as a spontaneous gesture carried out without any prior dialogue, or at the wrong timing, i.e. just a few days before the scheduled celebration of marriage, or a succession of acts imputable to one of the betrothed, such as unacceptable behavior punctuated by humiliation or insults directed at the other. Whether the abuse was committed by unexpectedly breaking the engagement or by wrongful conduct that caused the other person to quit, the result is the same, namely the right to compensation in favor of the victimized party, as opposable to the party who is guilty for breaking the engagement.

The compensation may apply, according to art. 269 para. (1) of the new Civil Code, to expenses incurred or contracted for marriage, only to the extent where they were appropriate to the circumstances, as well as for any other damage caused.

This includes, for example, expenses incurred or contracted for the marriage ceremony, but one could equally talk about the damage represented by expenses related to obtaining or preparing the family home, for instance, a house that, given its surface area, location, etc., would not have been purchased without marriage prospects. We believe that whenever engagement entails living together, factual cohabitation, especially if lasting, can provide factual elements to amplify both the material and the moral component of the incurred damage. In any case, guiltily breaking the engagement must be the cause of the claimed damage; in this regard the provisions of art. 269 Civil Code leave no doubt. The burden of proof for elements of liability connected to breaking the engagement is on the plaintiff. The right of action for damage caused by breaking the engagement is prescribed within one year after the engagement was broken, art. 270 of the Civil Code.

Therefore, the source of liability is chargeability for breaking the engagement (and not the act of breaking the engagement itself), if and insofar it caused moral or material damage to the party that is innocent of the rupture. De lege lata, the ground for this is in the rules of common law in matter of tort. The solution is the same if the contractual theory of engagement is shared, as liability is not contractual but rather pertains to tort law, if it is determined that termination, as a unilateral manifestation of will, was abusive.

Romanian jurisprudence before 1948 had the occasion to rule on the effects of breaking the engagement, stating that it can only entail than tort liability, as engagement is not a contract, and that the party guilty of breaking relationship can be ordered to pay both material and moral compensation.

There are elements outlining the structure of tort liability for one's own actions, provided for by art.1357 para. (1) of the new Civil Code: "he who causes damage to another by an unlawful act, committed with intent or fault, is obliged to pay compensation." We believe it is necessary to mention that the text of the law incorporates the provisions initially imposed by art. 998-999 of the 1864 Civil Code and configures the general conditions of liability for one's own actions, namely: the existence of a wrongful act, the existence of damage, the existence of a causal link between the wrongful act and the damage and, last but 
not least, the existence of fault, in any of its forms, according to art. 16 para. (4) of the new Civil Code.

Italian legal literature states, for the most part, the non-contractual nature of the obligation to pay compensation, with a reservation regarding tort liability. Some authors believe that this is a statutory, ex lege obligation, as it is unacceptable that the exercise of the freedom to choose whether to enter into marriage or refuse to do so, even after having promised, may acquire illicit connotations, for it would be tantamount to indirectly admitting that the fundamental right to marriage may suffer limitations on the basis of marital promises that are not binding.

French jurisprudence, in matters of "dissolution" of engagement, as well as in matter of abusive rupture of a consensual union, constantly admits that the one who suffered from the abusive breaking of engagement is entitled to compensation under the rules of tort liability ${ }^{32}$.

\section{J. Elements of comparative law \\ Swiss Civil Code}

The regulation of engagement in Switzerland is done by art. 90-93 of the Civil Code. As provided in the Romanian and Italian civil codes, the Swiss Civil Code states, in article 90, that the law does not grant a right of action to force marriage on the engaged person who refuses. In addition to the two above-mentioned codes, some rules are enforced on the ability of persons who may enter into a valid engagement only by proxy, namely minors and incapable persons. The provision is objectionable, on the argument that engagement is a personal act and should be left to the discretion of the person with full capacity of exercise.

Article 91 of the Swiss Civil Code, concerning the returning of gifts in case of disengagement, are similar to those in the new Romanian Civil Code. Thus, the betrothed may require the restitution of the gifts in case of disengagement, unless one of them has died or the gifts were acquired. If these gifts no longer exist in nature, the return is made depending on unjust enrichment. Although the Swiss Civil Code does not expressly state this, as does the new Romanian Civil Code, it could be interpreted to refer to gifts made expressly for the purpose of marriage, and not every gift given during the engagement.

Regarding the scope of good faith, it is a novelty to the Romanian and Italian civil codes. Article 92 of the Swiss Civil Code provides: "If one of the betrothed decided on the marriage, on good faith, which occasioned expenses or the loss of earnings, s/he may require appropriate financial participation of the other, provided that it is not inequitable in relation to the entirety of circumstances."

The difference from the Romanian legislation on granting compensation primarily consists of:

a. the new Romanian Civil Code refers to the party that may be required to pay compensation, namely the one that broke the engagement abusively, whereas the Swiss Civil Code mentions the party that may require such compensation, namely the one that incurred, in good faith, such expenditures.

We believe that the Romanian regulation, although objectionable in terms of the lack of a definition or circumstances that qualify an attitude as abusive in the case of breaking the engagement, is still preferable to the Swiss one, which circumstantiates the good faith of the person who may require and not the one who may be required to pay compensation, as it would be natural in engaging the civil liability to a person;

b. the new Romanian Civil Code extends the scope of possibility for seeking compensation and for "any other damage", as compared to the Swiss Civil Code, which is limited to engaging expenses or loss of earnings in relation to marriage.

\footnotetext{
${ }^{32}$ E. Florian, op. cit., 2011, p. 20, with reference to J-J. Lemouland, in "Droit de la familie", by P. Murat (coordinator), op. cit., p. 53-54, no. 111.72 and in terms of liability grounds for breaking the engagement, p. 458, no. 143.11-143.12.
} 
We believe that the Swiss regulation, like the Italian one, in this respect, is more concise and less likely to be interpreted inconsistently, as might be the case with Romanian legislation.

\section{The Italian Civil Code}

The regulation relevant in the Italian Civil Code is brief, art. 79-81, and it begins by stating the rule according to which the promise of marriage cannot force the party who breaks it to enter into marriage.

In accordance with art. 80, the engaged person can demand the return of gifts made in consideration of the promise of marriage, if the marriage does not take place.

It is noted that, similar to the regulation in the new Romanian Civil Code, the obligation to return the gifts is not limited to gifts made between the betrothed, as the law does not exclude $a b$ initio the restitution of gifts made to the betrothed by third parties.

Article 81 of the Italian Civil Code introduces liability for guiltily breaking the engagement, which only takes effect when the engagement was entered into by an authentic document or under private signature (i.e., by written document, which entails a more accurate proof of the real intention of the parties to enter into marriage). Liability is engaged only when a party breaks the engagement "without reasonable grounds".

It is noted that, here, the term "abusively", as used in the Romanian legislation, is not employed, but the idea of justification or even fault remains. The second paragraph of art. 81 states, similar to the regulation in the Romanian Civil Code, that similar obligations are incumbent on the promiser, who "of their own fault, gave the other a reason to break the engagement".

An important element is the fact that Art. 81 of the Civil Code obliges the promiser who broke off the engagement without reasonable grounds to indemnify the other for damages caused by "expenditures incurred and obligations contracted for marriage", but it does not regulate on extending liability to any other damage caused. Basically, the law eliminates the possibility to remedy the moral damage or to compensate for the lost profit, the liability being strictly limited to the above-mentioned elements.

The Italian law also provides that reimbursement of expenses and obligations is made to the extent where they were made, according to the state of the parties.

As a general element, we note the more restrictive conditions in engaging liability for breaking the engagement, as compared to the new Romanian Civil Code.

To summarize, the Italian law engages liability only if the engagement was entered into by an authentic document or under private signature, and the content of liability is limited to expenses and obligations assumed for the purpose of marriage, without giving the possibility to remedy other damages.

\section{Common law}

The Anglo-Saxon system has known major changes in jurisprudence over the last two centuries $^{33}$, as far as the effects of breaking an engagement are concerned. These changes have occurred due to the belief that there have been abuses in the exercise of such actions, as well as to the current of opinion according to which "love and law are incompatible."

In a first phase of Anglo-Saxon law in the United States of America, the owner of the action was the woman who had been promised to be taken into marriage and later deserted. She could seek compensation through an action for "breach of promise" been known since the Victorian era of Anglo-Saxon law in the United Kingdom ${ }^{35}$. Compensation first consisted of remedying material damage. However, since the twentieth century, compensation included damage for loss of earnings that the woman would have had

\footnotetext{
${ }^{33}$ R.Tushnet - Rules of Engagement, Yale Law Journal, June, 1998, 107 Yale L.J. 2583, p. 2.

${ }^{34}$ Also called "heart balm" action, according to R. Tushnet - Rules of Engagement, Yale Law Journal, June, 1998, 107 Yale L.J. 2583, p. 2.

${ }^{35}$ M. Grossberg - Governing the hearth: Law and the family in nineteenth century America, 1985, p. 33- 38; G.

S. Frost - Promises broken: courtship, class and gender in Victorian England, 1995, p. 80-97.
} 
as a result of the marriage, the damage for loss of opportunity to marry someone else (e.g., due to loss of virginity or birth of a child), but also the damage for emotional distress caused as a result of breaking the engagement. The change occurred in terms of shifting the center of attention from the economic benefits lost as a result of not concluding the marriage to the moral emotional distress of the woman. After this change, the American courts faced difficulties in assessing such compensation for moral damages ${ }^{36}$. Between 1930 and 1950, due to frequent situations where women came to blackmail wealthy men through "breach of promise" action, many American States ${ }^{37}$ repealed this possibility.

The main reasons that led to the repeal were those related to the invocation of the equal status of women to men. Marriage was no longer, in the view of the feminist current, the essence of a woman's existence, and the action in question did nothing but encourage women to see only the economic benefits of their relationship with a man, and not place them on a position of equality ${ }^{38}$.

Reformists ${ }^{39}$ supported the declining importance of the institution of seduction, as the loss of virginity was no longer regarded as something that could ruin a woman's life; more often these women were able to find a job and another man to marry. Moreover - they asserted - marriage was misunderstood because it should have been impossible to measure it in money. Since the woman was becoming increasingly freer to make plans in life, marriage was becoming more and more a relationship based on affection and less on economic issues, as had been the case in the past. Consequently, the removal of economic elements from the "breach of promise" action sought to modernize the approach to this action. The only economic element that was kept as an object of the action was related to engagement gifts, and they could be seen as a symbol of love and not as an intrinsic economic element.

From a legal point of view, action was considered an anomaly of the common-law system, as it contained both contractual elements, due to the existence of the promise of marriage, and tort elements, since it was not required to prove the existence of an agreement between the two with respect to marriage, but the woman's simple statement sufficed and it could be supported by witnesses ${ }^{40}$.

Likewise, the assessment of the moral damage, consisting of emotional distress caused by the rupture of engagement, was criticized on the rationale that "love cannot be treated as a market transaction" 41 and relations within marriage and engagement cannot be expressed in money.

By the 1950s, breaking an engagement could only cause emotional distress, which could not be expressed in money. Only gifts given in advance between the partners, for the purpose of marriage, could be the subject of action. One such gift is the engagement ring ${ }^{42}$ that is traditionally offered only in consideration of marriage, unlike other gifts, such as cars or clothes, which can also be given at birthdays and other events ${ }^{43}$. Action for the return of such goods is based on notions such as: conditional gift, restitution, unjust enrichment ${ }^{44}$, but

\footnotetext{
${ }^{36}$ R. Tushnet - Rules of Engagement, Yale Law Journal, June, 1998, 107 Yale L.J. 2583, pag.2;N.P. Feinsinger Legislative Attack on "Heart Balm", 33 MICH. L. REV. 979, 986-96, 1935; Lea Vander Velde - The Legal Ways of Seduction, 48 STAN. L. REV. 817 (1996).

${ }^{37}$ Indiana was the first state to adopt this change in 1935, according to M.B.W. Sinclair-Seduction and the Myth of the Ideal Woman, 5 LAW\&INEQ. J. 33, 65\&n.n.237-39 (1987).

${ }^{38}$ H. Spiller Daggett - Legal essays on family law, 1935, p. 39.

39 J. E. Larson - Women understand so little, they call my good nature deceit: A feminist rethinking of Seduction, 93 COLUM. L. REV. 374, 379, 397-99 (1993).

${ }^{40}$ M. Grossberg - Governing the hearth: Law and the family in nineteenth century America, 1985, p. 33. 38; N. P. Feinsinger - Legislative Attack on "Heart Balm”, 33 MICH. L. REV. 979, 986-96, 1935.

${ }^{41}$ R. Tushnet - Rules of Engagement, Yale Law Journal, June, 1998, 107 Yale L.J. 2583, p. 4.

${ }^{42}$ M. F. Brinig - Rings and Promises, 6 J.L. ECON. \& ORG. 203, 206 (1990); Viviana A. Zelizer - The social meaning of money 99-101 (1994).

${ }^{43}$ R. Tushnet - Rules of Engagement, Yale Law Journal, June, 1998, 107 Yale L.J. 2583, p. 4.

${ }^{44}$ Heartbalm Statues and Deceit Actions, 83 MICH. L. REV., 1770, 1786-87 (1985).
} 
still combines elements of tort and contract, as was the case with the "heart balm" action in the past.

The action for return of property given between the betrothed has known, in its turn, three jurisprudential stages in the United States of America ${ }^{45}$.

Thus, in a first stage, the betrothed were forced to return each other the goods when they broke the engagement. Subsequently, given the changes in family law according to which human relationships were too complex to be qualified in terms of fault, the restitution of property no longer rested on fault. Recently, this concept has evolved in the conditional gift theory, and the condition was marriage, with the obligation to return the gift if the marriage did not take place.

In the first stage, the basis for returning gifts given between the betrothed was the existence of fault: the fiancée had to return the engagement ring if she broke the engagement, but the same did not happen if the engagement was broken by the fiancé. The fault lay with whoever broke the engagement, regardless of the reasons that caused this to happen, the person regarded as guilty being the one who announced the breaking of the engagement ${ }^{4}$.

The second phase began in 1965, when the State of New York amended the legislation, meaning that the action was permissible for the return of gifts made in consideration of marriage, if the latter did not take place. The action was not based on the need for proof of fault, but it was grounded in the objective fact of the marriage not taking place $^{47}$.

In the third stage, according to the conditional gift theory, the gift given on a condition that usually has to be explicit must be returned if the condition is not fulfilled ${ }^{48}$. In case of engagement rings, marriage is the default condition ${ }^{49}$. The condition was interpreted either as the donor's wish to marry ${ }^{50}$, or marriage itself $^{51}$. In cases of returning the engagement ring, U.S. courts chose the second interpretation.

Unlike American law, British legislation presumes that the engagement ring is an absolute gift of the woman, unlike other engagement gifts, which are conditional and must be returned if the engagement is broken, unless it was broken by fault of the person who made the gift ${ }^{52}$.

\section{Conclusions}

At a first glance, despite the arguments related to tradition and some (few) foreign legislations, it could be argued that the regulation of engagement in the new Romanian Civil Code does not respond to a perceived social need. We believe, however, that an appreciation from an obsolete (outdated) perspective would be wrong, as engagement can be the "antechamber" of marriage. So herein lies the legal interest in knowing who can enter into an engagement, under what conditions, how to put an end to an engagement and, in particular, what the consequences of breaking the engagement are.

The new Romanian Civil Code provisions contained in articles 266-270 are open to criticism on at least the following grounds:

a. they do not determine the legal nature of this union;

b.they do not impose the written form as a condition to end the engagement;

\footnotetext{
${ }^{45}$ R.Tushnet - Rules of Engagement, Yale Law Journal, June, 1998, 107 Yale L.J. 2583, p. 4.

${ }^{46}$ Case Spinnell vs. Quigley, 785 P. 2d 1149, 1150-51 (Wash. Ct. App. 1990), Cauza Stanger v. Epler, 115 A. $2 d$ 197 (Pa. 1955).

${ }^{47}$ Case Heiman vs. Parrish, 942 P. 2d 631, 635-38 (Kan. 1997), Cauza Vigil v. Haber, 888 P. 2d 455 , 457 (N.M. 1994); E. M. Tomko, Annotation - Rights in respect of engagement and courtship presents when marriage does not ensue, 44 A.L.R. 5th 1 68-78 (1997).

4838 AM. JUR. 2D Gifts, par. 81 (1996).

${ }^{49}$ Case Fierro vs. Hoel, 465 N. W. 2d 669, 671 (Iowa Ct. App. 1990).

${ }^{50}$ Case Coconis vs. Christakis, 435 N.E. 2d 100, 102 (Ohio County Ct. 1981).

${ }^{51}$ Case Lindth vs. Surman, 702 A. 2d 560, 561 (Pa. Super. Ct. 1997).

${ }^{52}$ S. Cretney, Statues - Law Reform (Miscellaneous Provisions) Act 1970, 33 MOD. L. REV. 534, 536 (1970).
} 
c. they substantiate the idea of liability for damages based on the idea of fault/guilt;

d.they leave it to the court to decide on the categories of damage that can engage the liability of the one who abusively breaks the engagement.

What would be desirable in future regulations is to separate the effects of breaking the engagement from the idea of fault or abuse. Without borrowing a particular model, it can be seen that both in the American and other legal systems, the evolution of jurisprudence and regulation has taken place in the direction of removing the subjective evaluation on such sensitive elements as human relationships and in the direction of a stricter evidence regime (not by any available means) for a promise of marriage, when it legal effects such as engaging liability are to be determined.

\section{Bibliography}

The new Romanian Civil Code, Law no. 287/2009, published in the Official Gazette of Romania, Part I, no. 511 of 24 July 2009;

F.A. Baias, M. Avram, C. Nicolescu - Amendments to Family Code brought by Law no. 288/2007, in „Law” Review no.3/2008;

Law no. 202/2002 on equal opportunities and treatment between men and women, republished in the Official Gazette, Part I, no. 150 of 1 March 2007;

I.P. Filipescu, A.I. Filipescu - Treatise of Family Law, 8th Edition, revised and supplemented, "Universul Juridic" Publishing House, Bucharest, 2006;

E. Florian - Family Law, „Limes” Publishing House, Cluj - Napoca, 2003;

G. Boroi - Civil law. General part. Persons., Ed. All Beck, 2002;

C. Stătescu, C. Bârsan - Civil law. General theory of obligations, Ed. All Beck, 2002;

A. Bacaci, V. Dumitrache, C. Hageanu - Family Law, "All Beck" Publishing House, Bucharest, 1999;

C. Hamangiu, N. Georgean - Annotated Civil Code, 1st Volume, republished, All Beck Publishing House, Bucharest, 1999;

R.Tushnet - Rules of Engagement, Yale Law Journal, June, 1998, 107 Yale L.J. 2583;

A.R. Ionaşcu - Romanian Civil Law, Vol. II, Family Law, Sibiu, 1941, page 18; C. Hamangiu, I. Rosetti - Bălănescu, Al. Băicoianu - Treatise of Romanian Law, Vol. I (republished), All Publishing House, Bucharest 1998;

Case Lindth vs. Surman, 702 A. 2d 560, 561 (Pa. Super. Ct. 1997);

M. Grossberg - Governing the hearth: Law and the family in nineteenth century America, 1985, pag. 33-38; G. S. Frost - Promises broken: courtship, class and gender in Victorian England, 1995;

J. E. Larson - Women understand so little, they call my good nature deceit: A feminist rethinking of Seduction, 93 COLUM. L. REV. 374, 379, 397-99 (1993);

M. F. Brinig - Rings and Promises, 6 J.L. ECON. \& ORG. 203, 206 (1990);

Case Fierro vs. Hoel, 465 N. W. 2d 669, 671 (Iowa Ct. App. 1990);

M. Grossberg - Governing the hearth: Law and the family in nineteenth century America, 1985;

Case Coconis vs. Christakis, 435 N.E. 2d 100, 102 (Ohio County Ct. 1981);

Cretney, Statues - Law Reform (Miscellaneous Provisions) Act 1970, 33 MOD. L. REV. 534, 536 (1970);

D. Alexandresco - Theoretical and practical explanation of the Romanian civil law as compared to the older law and with the main foreign legislations, National Printing House, Iaşi, 1898;

I. Chelaru - Marriage and divorce. Judicial issues on civil, religious and comparative law

matters - Publishing House „A92 Acteon”, page 27;

Reasoning on the regulation of engagement in the Civil Code of Carol the Second, lectured by the ministry of justice, Victor Iamandi, in November 1939; 
The Civil Code of Carol II, promulgated by the High Royal Decree no. 3993 of 7 November 1939 and published in the Official Gazette no. 259, Part I, of 8 November 1939;

Civil Code of Carol the Second, enforced by the High Royal Decree no. 3993 of 7 November 1939 and published in the Official Journal no. 259, Part I, of 8 November 1939;

H. Spiller Daggett - Legal essays on family law, 1935;

„Pravila” (ancient term for regulation) of Matei Basarab and „Pravila” of Vasile Lupu (in force during 1652 - 1711), Code of Andronachi Donici (in force until 1817), Calimach Code and

Caragea Code (in force between 1817 - 1832);

The 1900 German Civil Code; The Swiss Civil Code; The Italian Civil Code; The Romanian Constitution. 